Portland State University

PDXScholar

\title{
Modifying Managerial Accounting Tools for Microbusiness Practices
}

Sydney A. Beard

Portland State University

Follow this and additional works at: https://pdxscholar.library.pdx.edu/honorstheses Let us know how access to this document benefits you.

\section{Recommended Citation}

Beard, Sydney A., "Modifying Managerial Accounting Tools for Microbusiness Practices" (2017).

University Honors Theses. Paper 383.

https://doi.org/10.15760/honors.378

This Thesis is brought to you for free and open access. It has been accepted for inclusion in University Honors Theses by an authorized administrator of PDXScholar. Please contact us if we can make this document more accessible: pdxscholar@pdx.edu. 
Modifying managerial accounting tools for microbusiness practices

$$
\text { by }
$$

Sydney Beard

An undergraduate honors thesis submitted in partial fulfillment of the requirements for the degree of

Bachelor of Arts

in

University Honors

and

Accounting

Thesis Advisor

Dr. Lihong Qian

Portland State University 


\section{TABLE OF CONTENTS}

$\begin{array}{lr}\text { ABSTRACT } & 2\end{array}$

$\begin{array}{lr}\text { INTRODUCTION } & 2\end{array}$

$\begin{array}{ll}\text { KEY CONCEPTS } & 3\end{array}$

$\begin{array}{lr}\text { MICROBUSINESSES } & 3\end{array}$

$\begin{array}{ll}\text { MANAGERIAL ACCOUNTING } & 3\end{array}$

$\begin{array}{lr}\text { THE BALANCED SCORECARD } & 4\end{array}$

LITERATURE REVIEW 24

LITERATURE GAP

PERCEPTIONS OF MANAGERIAL ACCOUNTING TOOLS

ADAPTING THE BALANCED SCORECARD 28

SUMMARY OF FINDINGS IN RELATION TO MICROBUSINESSES 11

CLIENT PROJECT \& RECOMMENDATIONS 12

COSTING TOOL

$\begin{array}{lr}\text { BALANCED SCORECARD } & 14\end{array}$

$\begin{array}{lr}\text { CONCLUSION } & 15\end{array}$

$\begin{array}{lr}\text { APPENDIX } & 16\end{array}$

$\begin{array}{lr}\text { REFERENCES } & 18\end{array}$ 


\section{ABSTRACT}

During the spring term of 2017, I worked with a local microbusiness in my Business Capstone class. This microbusiness presented a distinct need for managerial accounting tools with difficulties managing their cost of goods and understanding profitability of their products. I conducted a literature review surrounding two main topics: product costing tools and performance measurement tools for small businesses. I found that while many of these tools can become too complex for a small business to maintain, they can be useful if they are simplified and made more manageable. Through my research and discussions with the Capstone client, I developed two main recommendations regarding product costing and performance measurement for microbusinesses.

\section{INTRODUCTION}

In my personal experience in managerial accounting classes, I have noticed that nearly all examples of costing tools and nonfinancial performance measurement are put into terms of how large organizations would use them. I have always questioned whether small companies use these tools in the same way, if at all. Microbusinesses are an integral part of the US economy, yet they are continually overlooked in accounting research. My intention for this paper is to highlight the importance of managerial accounting tools for businesses of all sizes and to encourage further avenues of research for our country's tiniest businesses.

My work with my Business Capstone Client will focus on costing systems and performance measurement systems including nonfinancial data. I will explore the potential pros and cons of implementing different costing systems and examine the potential use of the Balanced Scorecard for my Capstone Client and other microbusinesses. My research will ultimately lead to a recommendation of preferred managerial accounting tools and any modifications that can be made to make these tools the most beneficial to the client. 
The remainder of this introduction provides explanations of a few important concepts. Next, I provide a literature review and uncover the current avenues of research and perceptions regarding managerial accounting tools. Then I discuss my key findings from the literature review and their relevance for microbusinesses. Lastly, I introduce my Business Capstone Client project and provide my final recommendations for the client.

\section{KEY CONCEPTS}

\section{MICROBUSINESSES}

The Association for Enterprise Opportunity defines a microbusiness as an enterprise with fewer than five employees, including the business owner. Microbusinesses make up an incredibly large segment of all small businesses in the U.S. economy. In 2014 there were 3.6 million documented microbusinesses in the U.S. (United States Census Bureau). That is roughly $62 \%$ of all documented businesses in the country (United States Census Bureau). Microbusinesses are popular because of their flexibility and low barriers to entry. A college degree is not required and the majority of owners initially finance their businesses with personal savings (AEO). Microbusinesses are incredibly relevant to our local economy, as 59\% of Oregon's businesses were characterized as microbusinesses in 2014 (United States Census Bureau). Because my capstone client consists of only the owner, who performs all business functions, they can be categorized as a microbusiness.

\section{MANAGERIAL ACCOUNTING}

Most are familiar with the practice of financial accounting, which focuses on the reporting of financial information based on Generally Accepted Accounting Principles (GAAP) set by the Financial Accounting Standards Board. The main purpose of financial accounting is to report information to external users such as investors, banks, and governmental agencies. Managerial accounting, on the other hand, is intended for users inside the business. Managerial accounting is the process of measuring, analyzing, and reporting financial and nonfinancial information that helps managers make decisions 
in order to meet the goals of a business (Datar, Horngren, \& Rajan 2015). Two important things to think about regarding managerial accounting practices are: how will this information assist managers to do their jobs better, and do the benefits of producing this information exceed the costs (Datar, Horngren, \& Rajan 2015).

\section{THE BALANCED SCORECARD}

The Balanced Scorecard (BSC) is a performance measurement tool that was developed in the early 1990's by Drs. Kaplan and Norton of the Harvard Business School. The BSC focuses on four main perspectives (customers, internal business processes, learning and growth, and financials) and each area can be customized with goals and measurements that best fit a business's needs (Kaplan \& Norton 1992). I will be exploring the possibility of adapting this tool for my capstone client. Ultimately the potential implementation of this tool will need to undergo a cost-benefit analysis, to determine if it is worth pursuing for my client's microbusiness.

\section{LITERATURE REVIEW}

This literature review provides further support for my discussion of managerial accounting practices in microbusinesses. I begin by discussing the literature relevant specifically to microbusiness practices and shed more light on the need for such research. Next I will examine the research regarding small and medium enterprises and the current perceptions of managerial accounting tools in these kinds of companies. Lastly I will look into the use of the Balanced Scorecard in SMEs and the successes and failures surrounding this tool.

\section{LITERATURE GAP}

The literature surrounding this topic tends to focus on managerial accounting practices of small and medium enterprises (SMEs) in comparison to managerial accounting practices at large enterprises. The U.S. Department of Commerce categorizes businesses with less than 100 employees as "small enterprises" and businesses with more than 100 but less than 500 employees as "medium enterprises". Because of this rather broad definition of a small business, it can be problematic to suggest a managerial accounting 
practice to all "small businesses". Discernibly, an enterprise with 80 employees will have much different financial and human capital resources than an enterprise with less than 5 employees. Any suggestions of managerial accounting tools for microbusiness will need to undergo a cost-benefit analysis to ensure that the tools will not take up too many resources and are realistic to use in day-to-day business practices.

During my research, I was only able to find one article that discussed the importance of managerial accounting knowledge for microbusinesses. As explained in their article, Datar, Epstein, and Yuthas (2009) worked with and studied the practices of microentrepreneurs in many impoverished countries around the world. The article provides the example of a Nicaraguan woman making and selling tortillas from her home who doesn't know what each tortilla costs to make, how many she should make each day in order to make the best profit, or how the business can possibly expand. Datar et al. (2009) found that all of the microbusiness owners they worked with needed education on topics such as: cost management, productivity enhancement, budgeting, risk management, and identifying opportunities. The article also explained that while some of these microbusinesses may have access to financial capital through microfinance loans, this isn't enough to make their businesses succeed. Many of the microentrepreneurs lack the knowledge and skills needed to use and manage the financial capital. The application of management of accounting techniques often separates the successful microbusinesses from the failures and gives the owners new insight to how their business should function (Datar et al. 2009).

The points made in the article referenced above provide further reasoning behind my motivation for this research topic. As I mentioned earlier, this was the only article I was able to locate that dealt specifically with microbusinesses and how managerial accounting relates to them. The same skills that the authors found they needed to teach these microentrepreneurs are the skills that accounting students learn every day in our basic managerial accounting classes; yet, these topics are taught and researched in regards to how they are used by large companies. In interviews with various SMEs, Armitage, Webb, and Glynn (2015) specifically chose not to include microbusinesses in their sample because they felt those businesses would be "considerably less likely" to 
use anything other than very basic accounting techniques. I will further discuss the implications of these interviews in the next section.

\section{PERCEPTIONS OF MANAGERIAL ACCOUNTING TOOLS}

There is a fair amount of research on the implications of managerial accounting on small and medium enterprises. SMEs require specific attention when it comes to managerial accounting practices because they tend to have a distinct set of resources and face some distinct challenges in comparison to large enterprises (Lopez \& Hiebl 2015). Large enterprises need to have a bigger, more complicated operating environment in order to maintain communication, coordinate activities, and handle the complexity of their operations (Armitage, Webb \& Glynn 2015). Because of their generally limited organizational structures, SMEs are often more flexible and adaptable to changes (Lopez \& Hiebl 2015). However, these businesses also have limited access to resources compared to their larger counterparts, therefore, they must find ways to manage their scarce resources in order to compete in their respective markets (Lopez \& Hiebl 2015). SMEs are usually focused on "search" activities, such as determining customer preferences, while large enterprises are focused on "executing” (Blank 2012 as cited in Armitage, Webb, \& Glynn 2015). Management of resources can be best achieved through the use of managerial accounting and proper information and control systems (Lopez \& Hiebl 2015).

In recent interviews with 22 SMEs, Armitage et al. (2015) found that the most commonly used managerial accounting tools were: operating budgets, generalized costing systems, segment reporting, and financial statement analysis. These particular SMEs almost always used a job costing system where a "job" was defined as either a specific client or project. Firms mainly used Microsoft Excel spreadsheets to track their costs and a few either developed or purchased more sophisticated programming for this purpose. These SMEs explained that they used their costing systems to assist them in setting appropriate prices, managing profitability, and making decisions about whether a certain product should be kept or dropped from production. The researchers also found that the smaller the company, the more likely they were to focus only on the cash component for budgeting. A few of the medium sized companies also utilized operating 
budgets as tools for planning and control. (Armitage et al. 2015)

In a similar study, Abdel-Kader and Luther (2006) surveyed SMEs in the British food and drink industry and found that variable costing (such as job costing) was much more common than forms of absorption costing. They also found that these companies use budgeting often in order to plan and control their costs. The survey results showed that these companies were aware of the importance of allocating overhead costs to their products or services and the techniques to do so, but believed that it was not worth implementing them on a regular basis. Interestingly, the surveyed enterprises also regularly analyzed their competitive positions in the market. The most used management accounting techniques among these companies were: budgeting, performance evaluation based on financial measures, product profitability analysis, and customer profitability analysis. (Abdel-Kader \& Luther 2006)

Balakrishnan et al. (2012) examined the pros and cons of various sophisticated product costing and overhead allocation systems. They found that traditional volume based systems (such as job costing or process costing) were the simplest to understand and easiest to implement because they make use of readily available data. These systems tend to rely on very few cost pools and make use of standard, well measured cost drivers. Activity based costing systems, on the other hand, require much more data to implement and can become complicated quickly due to the number of activity pools and the kinds of assumptions that must be made. The authors also examined resource consumption and time driven activity based costing. Essentially, they found that costing systems become more difficult to implement and maintain as they become more complex. More complicated costing systems can be more accurate, but are better suited for large enterprises who can devote more resources to maintaining them. (Balakrishnan et al. 2012)

Due to the relatively young age of my Capstone client's business, I believe it would also be useful to examine the managerial accounting practices of start-up companies. The start-up phase of a company is similar to the state of a well established small or medium enterprise: there is very little organizational architecture in place. Davila and Foster (2005) found that budgets are the earliest management accounting tools adopted by 
their sample of start-ups. They noted that there are various factors influencing the adoption of managerial accounting techniques: the scale of the company, the CEO's previous experience, and the presence of external investors. The need for management accounting increases as the scale of the company increases. The authors also found a positive association between the adoption of managerial accounting techniques and company growth within their sample. (Davila \& Foster 2005)

\section{ADAPTING THE BALANCED SCORECARD}

The Balanced Scorecard (BSC) has been applied to countless large organizations with great success, but still relatively little is known about the use of this tool by smaller companies. By and large, the traditional method of measuring a company's performance by financial metrics alone has essentially disappeared from large companies (Basu 2001 as cited in Aspinwall, Rodrigues, \& Sousa 2006). As discussed earlier the BSC focuses on four main perspectives of performance measurement: customers, internal business processes, learning and growth, and financials. Nonfinancial measures are at the heart of describing the strategy of a business and developing a set of measures that can clearly communicate how successfully that strategy is being implemented (Aspinwall et al. 2006).

For a look at the current perceptions SMEs have about the BSC, I will return to a few of the interview and survey studies mentioned in the above section. Armitage et al. (2015) found that none of their interview subjects used the Balanced Scorecard for performance tracking because they believed it was "too complex" for small companies and the four categories were "too restrictive". However, all of the companies noted measuring financial and non-financial metrics that they called "key indicators" or “critical performance measures" (Armitage et al. 2015). Abdel-Kader and Luther (2006) found that their survey participants tracked nonfinancial measures regarding customers more frequently than other types of nonfinancial measure. Measures regarding employees (a.k.a. learning and growth) were monitored the least (Abdel-Kader \& Luther 2006). 
Aspinwall, et al. (2006) surveyed 52 SMEs and found that there were a few common barriers to the adoption of the BSC. The main obstacles to adoption were: computer system issues, lack of top management commitment, training of employees to understand and use the system, difficulty in defining new performance measures, and the cost of maintaining the performance measurement system. The cost of maintaining a performance measurement system is particularly important for SMEs, as they often have limited access to resources in comparison to large companies. Unfortunately, there is a gap between the theory and knowledge that SMEs have surrounding the BSC and the actual practice of using the BSC (Aspinwall et al. 2006).

Small businesses rarely take the time to undergo a comprehensive review of their business strategy and activities (Cook \& Wolverton 1995). From the interview and survey responses discussed above, it is apparent that SMEs need an adapted way to use the Balanced Scorecard. Due to their organizational structure, SMEs require less information to carry out their operations and evaluate their performance, but the value of any information they can gather is crucial to their success (Von Bergen \& Benco 2004). By attempting to use the BSC in the same way that large enterprises do, SMEs can potentially create a performance measurement system that is so broad that it can divert vital resources from the areas that need the most attention (Von Bergen \& Benco 2004).

"The root cause of either small business failure or poor performance is almost invariably a lack of management attention to strategic issues.” (Jennings \& Beaver 1997 as cited in Andersen, Cobbold, \& Lawrie 2001) The basic issues of strategic management are relevant to any business, regardless of size. Theses issues of focus are: the need for a clear sense of direction, understanding of the business model, and the need to focus and prioritize (Andersen et al. 2001). Particularly for SMEs, the Balanced Scorecard can be an opportunity for a company to translate their business strategy into action and create a focus for the future, not just a measure of past performance (Gumbus \& Lussier 2006). Because no one BSC fits all organizations, small business entrepreneurs should develop objectives, measures, and targets to guide improvement in all four measures of the Balanced Scorecard and development should be an ongoing process throughout the business’s life (Gumbus \& Lussier 2006). 


\begin{tabular}{|c|c|c|}
\hline Concept & Citation & Key Findings \\
\hline $\begin{array}{l}\text { Microbusinesse } \\
\text { s \& managerial } \\
\text { accounting }\end{array}$ & $\begin{array}{l}\text { Datar, } \\
\text { Epstein, \& } \\
\text { Yuthas (2009) }\end{array}$ & $\begin{array}{l}\text { Microentrepreneurs need education in cost management, throughput } \\
\text { enhancement, budgeting, risk management, and identifying } \\
\text { opportunities in order to help their businesses thrive. }\end{array}$ \\
\hline $\begin{array}{l}\text { Challenges of } \\
\text { SMEs }\end{array}$ & $\begin{array}{l}\text { Lopez \& Hiebl } \\
(2015)\end{array}$ & $\begin{array}{l}\text { SMEs are flexible and adaptable to changes, but have limited access to } \\
\text { resources in comparison to large enterprises. SMEs can best manage } \\
\text { these scarce resources through managerial accounting and control } \\
\text { systems. }\end{array}$ \\
\hline \multirow{2}{*}{$\begin{array}{l}\text { Surveys of } \\
\text { SMEs on } \\
\text { managerial } \\
\text { accounting } \\
\text { tools }\end{array}$} & $\begin{array}{l}\text { Armitage, } \\
\text { Webb, \& } \\
\text { Glynn (2015) }\end{array}$ & $\begin{array}{l}\text { Most commonly used tools were: operating budgets, generalized costing } \\
\text { systems, segment reporting, and financial statement analysis. }\end{array}$ \\
\hline & $\begin{array}{l}\text { Abdel-Kader } \\
\text { \& Luther } \\
(2006)\end{array}$ & $\begin{array}{l}\text { Most commonly used tools were: budgeting, performance evaluation } \\
\text { based on financial measures, product profitability analysis, and } \\
\text { customer profitability analysis. }\end{array}$ \\
\hline $\begin{array}{l}\text { Pros and cons } \\
\text { of sophisticated } \\
\text { costing tools }\end{array}$ & $\begin{array}{l}\text { Balakrishnan, } \\
\text { Labro, \& } \\
\text { Sivaramakris } \\
\text { hnan (2012) }\end{array}$ & $\begin{array}{l}\text { Traditional volume based systems are the simplest to understand and } \\
\text { easiest to implement. Costing systems become more difficult to } \\
\text { implement and maintain as they become more complex. }\end{array}$ \\
\hline $\begin{array}{l}\text { Start-up } \\
\text { companies }\end{array}$ & $\begin{array}{l}\text { Davila \& } \\
\text { Foster (2005) }\end{array}$ & $\begin{array}{l}\text { Budgets are the earliest management accounting tools adopted. Factors } \\
\text { influencing the adoption managerial accounting techniques: scale of the } \\
\text { company, CEO experience, and presence of external investors. }\end{array}$ \\
\hline $\begin{array}{l}\text { Surveys of } \\
\text { SMEs on the } \\
\text { Balanced } \\
\text { Scorecard }\end{array}$ & $\begin{array}{l}\text { Aspinwall, } \\
\text { Rodrigues, \& } \\
\text { Sousa (2006) }\end{array}$ & $\begin{array}{l}\text { Main obstacles to adoption: computer system issues, lack of top } \\
\text { management commitment, training of employees, difficulty in defining } \\
\text { new measures, and cost of maintaining the system. }\end{array}$ \\
\hline \multirow[t]{2}{*}{$\begin{array}{l}\text { Adapting the } \\
\text { Balanced } \\
\text { Scorecard }\end{array}$} & $\begin{array}{l}\text { Cook \& } \\
\text { Wolverton } \\
\text { (1995) }\end{array}$ & $\begin{array}{l}\text { Small businesses need a straightforward approach to the BSC that is } \\
\text { easy to prepare and interpret on a regular basis. Authors designed a } \\
\text { series of general questions for business owners to check in with } \\
\text { periodically and assess their progress. }\end{array}$ \\
\hline & $\begin{array}{l}\text { Von Bergen \& } \\
\text { Benco (2004) }\end{array}$ & $\begin{array}{l}\text { SMEs have a simpler structure than large organizations and should be } \\
\text { wary of creating a BSC that is too broad to manage. Information on } \\
\text { operations is crucial to SME success. }\end{array}$ \\
\hline \multirow[t]{2}{*}{$\begin{array}{l}\text { Strategic } \\
\text { Management }\end{array}$} & $\begin{array}{l}\text { Andersen, } \\
\text { Cobbold, \& } \\
\text { Lawrie (2001) }\end{array}$ & $\begin{array}{l}\text { Relevant issues for all businesses: the need for a clear sense of } \\
\text { direction, understanding the business model, and the need to focus and } \\
\text { prioritize. }\end{array}$ \\
\hline & $\begin{array}{l}\text { Gumbus \& } \\
\text { Lussier (2006) }\end{array}$ & $\begin{array}{l}\text { SMEs can use the BSC to translate business strategy into action and } \\
\text { create a focus for the future. Develop objectives, measures and targets } \\
\text { for all four categories of BSC and use for continuous improvement. }\end{array}$ \\
\hline
\end{tabular}




\section{SUMMARY OF FINDINGS IN RELATION TO MICROBUSINESSES}

Due to the lack of literature dedicated specifically to microbusinesses, I will relate my findings from the literature on SMEs to these much smaller entities. As the literature shows, all businesses regardless of size, can benefit from implementing managerial accounting tools. It is likely that many of the most commonly used tools by SMEs can also be used by microbusinesses. From the tools discussed by Armitage et al. (2015), and Abdel-Kader and Luther (2006), I believe that the most applicable tools to microbusinesses are: budgets and costing systems. For their small scale of operations, cash budgets are likely the most relevant to microbusiness practices. As shown in Davila and Foster (2005) budgets were the earliest managerial accounting tool adopted by their sample of startup companies and they found a positive correlation between adopting these tools and overall company growth. A cash budget can assist microbusinesses in managing their limited resources and ensure that they can take advantage of business opportunities as they arise.

There are many different kinds of product costing systems and they are continuing to become more sophisticated as time goes on. However, as shown in the literature, the benefits of implementing more advanced costing systems only outweigh the costs if you are a large company that can employ many people to maintain it. Therefore, it is best to recommend a simple and easy to maintain costing system for microbusinesses. I suggest job costing, as it is the simplest to understand and the easiest to implement (Balakrishnan et al. 2012). Job costing often does not require advanced technology or much time to maintain so it is perfect for microbusinesses to create something as simple as a Microsoft Excel spreadsheet and use it to track their costs.

Finally, there seem to be many differing opinions on the usefulness of the Balanced Scorecard for small businesses. In the particular case of microbusinesses, I believe that this tool needs to be simplified and easier to manage than the all-encompassing scorecards used by large corporations. In their article Cook and Wolverton (1995) designed their own "scorecard" and included questions related to various aspects of a business, such as management, marketing, human resources, and financial data. Their 
proposed scorecard focused on specific strategic performance indicators and was based on "yes/no" questions and a discussion of any actions that must be taken in the case of a “no" answer (Cook \& Wolverton 1995). However, simply answering these questions isn’t the end of the process. These questions are designed to get a business owner to think about their overall business strategy, how the different parts of their business are interrelated, and what kind of actions they can take to continually improve their business (Cook \& Wolverton 1995).

As the literature shows us, the need for understanding a business's overall strategy and strategic management is relevant for all entities regardless of size (Andersen et al. 2001; Von Bergen \& Benco 2004). I would suggest that microbusinesses invest the time in defining the business strategy and utilizing a similar scorecard to that developed by Cook \& Wolverton (1995). Due to their simple structures, it would be unnecessary for microbusinesses to develop a typical Balanced Scorecard, as this could quickly become too large and unmanageable. By developing or adapting an existing set of strategic performance questions, microbusinesses can routinely return to these questions annually, bi-annually, or quarterly, and assess their progress. This, again, can be done in a cost saving way, likely with Microsoft Word or Excel, without the need for expensive or complicated software. It is imperative that microbusiness owners manage their strategic objectives and are able to communicate them clearly to new employees as the business expands.

\section{CLIENT PROJECT \& RECOMMENDATIONS}

In the spring term of 2017 I worked with a team of students and a local microbusiness

for my Business Capstone class. For the purposes of this paper, I will conceal the name of my Business Capstone Client. The business will be referred to as "the Client" for the duration of this paper to provide anonymity. The Client is organized as a limited liability company (LLC) in the food production industry. The company consists of one full time employee, the owner, who performs all business responsibilities. The client produces small batch jams and sells them through an online platform, at local farmers markets, to small local retailers, and to a few small retailers on the east coast. In my 
discussion with the client I have learned that the company has difficulty managing their cost of goods sold due to seasonality and volatility in the purchasing prices of their raw materials. The client is subject to a seasonal supply chain, unpredictable berry harvests, and fluctuating raw material prices. This, in turn, affects their ability to maintain a consistent selling price for their products while still making a consistent profit for their business. The client is also considering expansion from a home kitchen work space to a rented commercial kitchen, taking on an additional employee, and adjusting their personal income from the business.

\section{COSTING TOOL}

My first priority for my client was to create a modified job (or recipe, as they produce a recipe based product) costing tool to help them understand their product costs and profit margins. I worked with one other member of my Capstone team to develop this tool. We began by choosing a simple, easy to use platform: Google Sheets. Google Sheets is very similar to Microsoft Excel, but because it is web based it can be accessed from any laptop, tablet, or mobile device easily and it is free to use. We felt that this ease of access was necessary for our client, as they are often away from their home office when making purchasing decisions.

This spreadsheet contains all costs for the business and breaks them down by batch of jam and profit margin per jar of jam. There is a Fixed Cost tab, where the client can enter in all fixed or indirect costs that they incur over the course of a year. Those fixed costs then get allocated to each jar based upon the total sales revenue from the previous year and the selling price of the jar. There are also separate tabs for their retail and wholesale sales because the client uses different selling prices for each. On each of these tabs there are tables for direct material (DM) costs and direct labor (DL) costs. Each tab has a summarizing table at the top that states what recipe they are costing, how many jars are produced in the batch, how much the total batch costs in DM and DL, the variable costs per jar, the fixed costs per jar, the selling price per jar, and the profit margin per jar. We have also included some conditional formatting in the spreadsheet to show the profit margin as green if it is above a certain percentage and red if it falls below that threshold. Lastly, because of the variability and often short notice of their 
produce purchases, we have included a "Potential Purchase" tool at the top of the sheet. The client can simply enter the pounds of fruit and the price per pound in this section and it will fill in to the direct materials table and produce the appropriate profit margin for that purchase price. The costs of all other materials remain stable from batch to batch, so they can remain in the table and don't need to be altered each time the client makes a purchase.

We have implemented this spreadsheet with the client on multiple occasions and have received positive feedback. I believe that this tool will allow them to understand what their product is actually costing them and whether or not they are making a good profit margin on their sales. This tool will also allow the client to account for their personal labor time and pay themselves accordingly. By allocating fixed costs to each jar, the Client will be able to see how expanding their operations will affect their business. Taking on additional employees and expanding into commercial kitchen space are expensive tasks. I hope that this costing tool will assist them in making these decisions, ensuring that they can pay new employee wages or pay rent and still be profitable. Please see the Appendix for a sample product tab and fixed costs tab of the product costing tool.

\section{BALANCED SCORECARD}

Through my research this term, I wanted to understand whether or not implementing the Balanced Scorecard would be useful for my Capstone Client. My assessment is: yes, it can be useful, but only if modified to a simpler and more manageable state. For example, this particular microbusiness only has one employee, the owner, so the learning and growth perspective of the BSC is not relevant to them because it often includes assessments such as employee satisfaction rates or levels of employee education.

Although a typical BSC method can not be directly applied to a microbusiness, the idea of a BSC method can still be applied, to the extent that the assessment focuses not only on the quantitative aspects of a business, but also the qualitative aspects, and that the performance metrics cover not only the business outcomes (e.g., profitability, growth 
rate, and market share), but also the business process (e.g., effectiveness of operation, efficiency of supply logistic management, and customer service).

I believe that the best way for my Client to utilize a BSC approach is to have a list of questions about various aspects of their business that they can go over annually or biannually to see if they are meeting goals and making progress. The first step in this process is to put their business strategy into writing and create a forward looking vision statement: where do they want their business to be in one, five, or ten years? The next step would be to either develop their own set of strategic questions or adapt some from another model, such as Cook and Wolverton's (1995) scorecard. I believe that by implementing this process and reassessing strategic initiatives regularly, my Client will have a better sense of where they want their business to be and what actions will get them there.

\section{CONCLUSION}

My intention for this paper was to highlight the importance of managerial accounting tools for businesses of all sizes and to encourage further avenues of research regarding microbusinesses. Through my literature review I examined the current avenues of research and SME perceptions surrounding various managerial accounting tools. I discussed my key findings in relation to microbusinesses and found that most tools can be modified and simplified to be used by any size of business. This research assisted me in my work with my Business Capstone Client, where I was able to develop a modified costing tool and recommend a modified approach to the Balanced Scorecard.

I believe the next steps for this research are to perform surveys of microbusiness owners around the US and assess which managerial accounting tools they have knowledge of and feel are the most useful for their tiny businesses. Without understanding what these businesses already do, we won't be able to make suggestions for future improvement. Microbusinesses make up a large portion of our American economy, and it is imperative that they are able to thrive. Managerial accounting is an incredibly important tool in ensuring that businesses of all sizes are able to reach their full potential. 


\section{APPENDIX}

\section{Product Cost Spreadsheet}

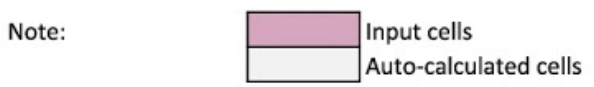

\begin{tabular}{|l|c|}
\hline RECIPE: & \\
\hline RECIPE YIELD: & $\$-$ \\
\hline TOTAL BATCH COST: & $(9 \mathrm{oz}$ jars $)$ \\
\hline & \\
\hdashline VARIABLE COST / JAR: & $\$ 0.00$ \\
\hline FIXED COST / JAR & $\$ 0.00$ \\
\hline COST / JAR & $\$ 0.00$ \\
\hline SELLING PRICE: & $\$ 0.00$ \\
\hline PROFIT MARGIN: & $100.00 \%$ \\
\hline
\end{tabular}

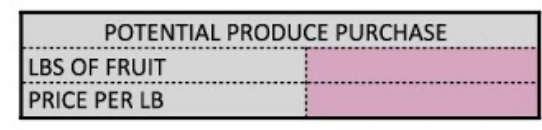

POTENTIAL PRODUCE PURCHASE LBS OF FRUIT

PRICE PER LB
TOTAL FIXED COST

Divided by 2016 SALES

Multiply SALE PER JAR

FIXED COST PER JAR
$\$$ -

$\$-$

$\$-$

DIRECT MATERIALS

\begin{tabular}{|c|c|c|c|c|c|c|c|c|c|c|c|}
\hline \multirow[t]{2}{*}{ INGREDIENT } & RECIPE & \multicolumn{2}{|c|}{$\begin{array}{l}\text { QUANTITY } \\
\text { PURCHASED }\end{array}$} & \multirow{2}{*}{$\begin{array}{c}\begin{array}{c}\text { PURCHASE } \\
\text { PRICE }\end{array} \\
\$-\end{array}$} & \multicolumn{2}{|c|}{ UNIT CONVERSION } & \multicolumn{2}{|c|}{ COST PER UNIT } & \multicolumn{2}{|c|}{ UNITS IN RECIPE } & \multirow{2}{*}{$\begin{array}{r}\begin{array}{r}\text { COST FOR } \\
\text { BATCH }\end{array} \\
\$\end{array}$} \\
\hline & & 0.00 & Ibs & & 0.00 & $0 z$ & $\$-$ & oz & 0.00 & $0 z$ & \\
\hline & & 0.00 & Ibs & $\$-$ & 0.00 & $0 z$ & $\$-$ & oz & 0.00 & $0 z$ & $\$$ \\
\hline & & & & & 0.00 & 02 & $\$-$ & oz & 0.00 & $0 z$ & $\$$ \\
\hline & & & & & 0.00 & $0 z$ & $\$-$ & oz & 0.00 & $0 z$ & $\$$ \\
\hline & & & & & 0.00 & $0 z$ & $\$-$ & oz & 0.00 & oz & $\$$ \\
\hline & & & & & 0.00 & $0 z$ & $\$-$ & oz & 0.00 & $0 z$ & $\$$ \\
\hline & & & & & 0.00 & $0 z$ & $\$-$ & oz & 0.00 & $0 z$ & $\$-$ \\
\hline & & & & & & & & & & TOTAL & $\$-$ \\
\hline
\end{tabular}

PACKAGING

\begin{tabular}{|c|c|c|c|c|c|c|c|c|}
\hline \multirow[t]{2}{*}{ ITEM } & RECIPE & $\begin{array}{l}\text { QUANTITY } \\
\text { PURCHASED }\end{array}$ & \multirow[t]{2}{*}{$\begin{array}{c}\text { PURCHASE } \\
\text { PRICE } \\
\end{array}$} & \multicolumn{2}{|c|}{ COST PER UNIT } & \multicolumn{2}{|c|}{ UNIT CONVERSION } & COST FOR BATCH \\
\hline & & & & $\$-$ & unit & 0.00 & units & $\$-$ \\
\hline & & & & $\$-$ & unit & 0.00 & units & $\$-$ \\
\hline & & & & $\$-$ & unit & 0.00 & units & $\$-$ \\
\hline & & & & $\$-$ & unit & 0.00 & units & $\$-$ \\
\hline & & & & $\$-$ & unit & 0.00 & units & $\$-$ \\
\hline & & & & & & & TOTAL & $\$-$ \\
\hline
\end{tabular}

DIRECT LABOR

\begin{tabular}{|c|c|c|c|c|c|}
\hline EMPLOYEE & TIME & WORK WEEK & $\begin{array}{c}\text { WEEKLY } \\
\text { PAY }\end{array}$ & HOURLY WAGE & COST FOR BATCH \\
\hline & & & & & \\
& & & & $\$-$ & $\$-$ \\
\hline
\end{tabular}




\section{Product Cost Spreadsheet}

Note:

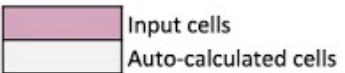

FIXED COSTS (BASED ON LAST YEAR'S NUMBERS \& ESTIMATES)

FARMERS MARKET BOOTH FEES

\begin{tabular}{|c|c|c|c|c|}
\hline MARKET & FEE & DATE & TIMES/YR & COST \\
\hline & & & & $\$$ \\
& & & $\$$ & $\$$ \\
\hline & & & $\$$ \\
\hline & & & $\$$ \\
\hline & & & $\$-$ \\
\hline
\end{tabular}

INDIRECT LABOR

\begin{tabular}{|c|c|c|c|c|}
\hline EMPLOYEE & \# WEEKS & HRS & WAGE & COST \\
\hline & & & & $\$-$ \\
\hline & & & & $\$-$ \\
\hline & & & & $\$-$ \\
\hline \multicolumn{4}{|r|}{ Total } & $\$-$ \\
\hline
\end{tabular}

OTHERS

\begin{tabular}{|c|c|c|c|}
\hline PURPOSE & FEE & QTY & COST \\
\hline & & & $\$-$ \\
\hline & & & $\$$ \\
\hline & & & $\$-$ \\
\hline & & & $\$-$ \\
\hline & & & $\$-$ \\
\hline & & & $\$-$ \\
\hline & & & $\$-$ \\
\hline & & & $\$-$ \\
\hline & & & $\$-$ \\
\hline & & & $\$-$ \\
\hline & & & $\$-$ \\
\hline & & & $\$-$ \\
\hline & & & $\$-$ \\
\hline & & & $\$$ \\
\hline & & & $\$=$ \\
\hline & & & $\$$ \\
\hline & & & $\$-$ \\
\hline & & & $\$-$ \\
\hline & & & $\$-$ \\
\hline & & & $\$-$ \\
\hline \multicolumn{3}{|r|}{ Total } & $\$-$ \\
\hline
\end{tabular}




\section{REFERENCES}

Abdel-Kader, M. \& Luther, R. (2006). Management accounting practices in the British food and drinks industry. British Food Journal, 108(5), 336-357.

Andersen, H., Cobbold, I., \& Lawrie, G. (2001). Balanced Scorecard implementation in SMEs: reflection in literature and practice. 2GC Active Management.

Armitage, H. M., Webb, A., \& Glynn, J. (2015). The Use of Management Accounting Techniques by Small and Medium-Sized Enterprises: A Field Study of Canadian and Australian Practice. Accounting Perspectives, 15(1), 31-69.

Aspinwall, E. M., Rodrigues, A. G., \& Sousa, S. D. (2006). Performance measures in English small and medium enterprises: survey results. Benchmarking: An International Journal, 13(12), 120-134.

Association for Enterprise Opportunity (AEO). (2013). Bigger than you think: The economic impact of microbusinesses in the United States.

Balakrishnan, R., Labro, E., \& Sivaramakrishnan, K. (2012). Product Costs as Decision Aids: An Analysis of Alternative Approaches (Parts 1 \& 2). Accounting Horizons, 26(1), 1-41.

Cook, R. A., \& Wolverton, J. B. (1995). A Scorecard for Small Business Performance. Journal of Small Business Strategy.

Datar, S. M., Epstein, M. J., \& Yuthas, K. J. (2009). Management Accounting and Control: Lessons for and from the World's Tiniest Businesses. Strategic Finance, 27-34.

Datar, S.M., Horngren, C.T., and Rajan M.V., (2015) Cost Accounting: A Managerial Emphasis. 15th ed. New Jersey: Pearson Education, Print.

Davila, A., \& Foster, G. (2005). Management Accounting Systems Adoption Decisions: Evidence and Early-Stage / Startup Companies. The Accounting Review, 80(4), 1039-1068. 
Gumbus, A., \& Lussier, R. N. (2006). Entrepreneurs Use a Balanced Scorecard to Translate Strategy into Performance Measures. Journal of Small Business Management, 44(3), $407-425$.

Kaplan, R.S., and Norton, D.P. (1992). The Balanced Scorecard - Measures That Drive Performance. Harvard Business Review. 70(1), 71-79.

Lopez, O. L., \& Hiebl, M. R. W. (2015). Management Accounting in Small and Medium-Sized Enterprises: Current Knowledge and Avenues for Further Research. Journal of Management Accounting Research, 27(1), 81-119.

United States Census Bureau (2014). Quick Facts United States.

Von Bergen, C. W., \& Benco, D. C. (2004). A Balanced Scorecard for Small Business. 